you I have a Horse worth $55 \$$ for the horse [10\$] I had at Ottumwa he was next thing to now horse Bob McCousland lied me out of $20 \$$ on the trade I made with him but I have made it up. if I ever gow back to Bonaparte (which I expect to if I live) I will try \& make it back of him. the boys are all well Brad J H Bell Sam \& Morgan. Morgan sends his best respects to you wishes you all the pleasure imadginable \& sais he wants you to Marry Sarhah before he comes back. I have had the best of health ever-since I left you and good Spirits. write soow that $I$ will get it by the middle or lat of August in California. give my respects to all inquiring friends. I remain your Brother till death

Robert Cresswell Jr

John M Cresswell. to

\title{
OLD HICKORY SPEAKS HIS MIND
}

Mr James K. Polk

Hermitage 19 May 1845

President U States

Dear Sir.

I have examined all the papers in the case of L.t Roherts of the Army, and if I was President I would not hesitate to restore him to his full rank in the Dragoons with all his pay and perquisites. He was unlawfully dismissed, and I would have Genl Scott know that in my administration injustice shall not be done to individuals to save the ends of "public policy." I do hope that you will learn Genl Scott his place as general in the Army, and have him know that his principle "that justice must yield to policy will not be the rule of your administration. I wish to see Lt Roberts fully restored.

Signed

ANDREW JACKSON

I was present at the Hermitage, and saw Genl Jackson write the letter of which the within is a copy.

Washington D C. 13 Dee 1852

R. Armstrong.

The original of this letter is in one of the Courts of Iowa, as evidence in a "libel suit," and cannot at present be procured from the files of the Court.

\section{B. S. Roner's}

L.t Col U.S.A

[On back of letter]

Genl Jacksons letter to Mr Polk

The last letter he ever wrote

[The foregoing letter with endorsements is from the collections of the Historical, Memorial and Art Department of Iowa. Editor Annals. J 
Copyright of Annals of Iowa is the property of State of Iowa, by \& through the State Historical Society of Iowa and its content may not be copied or emailed to multiple sites or posted to a listserv without the copyright holder's express written permission. However, users may print, download, or email articles for individual use. 